\title{
Infection of Maize by Clavibacter michiganensis subsp. nebraskensis Does Not Require Severe Wounding
}

Sally O. Mallowa, Gladys Y. Mbofung, and Sharon K. Eggenberger, Department of Plant Pathology and Microbiology, Randall L. Den Adel, Microscopy and Nanoimaging Facility, and Sheila R. Scheiding and Alison E. Robertson, Department of Plant Pathology and Microbiology, Iowa State University, Ames 50010

\begin{abstract}
Mallowa, S. O., Mbofung, G. Y., Eggenberger, S. K., Den Adel, R. L., Scheiding, S. R., and Robertson, A. E. 2016. Severe wounding is not necessary for infection of maize by Clavibacter michiganensis subsp. nebraskensis. Plant Dis. 100:724-731.

Goss's bacterial wilt and leaf blight of maize is caused by Clavibacter michiganensis subsp. nebraskensis. Infested residue is the primary source of inoculum and infection occurs via wounds caused by sand blasting, hail, or wind damage. The pathogen survives as an epiphyte on maize leaves and, because the disease has been observed on plants in the field with no obvious wounding, we wondered whether infection by epiphytic $C$. michiganensis subsp. nebraskensis and disease development could occur in the absence of severe wounding. Consequently, greenhouse experiments were done to evaluate disease development in the absence of wounding in ambient and increased humidity conditions. Maize plants at the V4 to V5 crop development stage were spray inoculated with a suspension of $C$. michiganensis subsp. nebraskensis $\left(10^{8}\right.$ cells $\mathrm{ml}^{-1}$ ). Leaf blight incidence was assessed on whole plants and individual leaves; epiphytic populations of $C$. michiganensis subsp. nebraskensis were monitored by dilution plating of leaf washes; and

epiphytic C. michiganensis subsp. nebraskensis colonization was visualized using scanning electron microscopy (SEM). Goss's leaf blight symptoms were observed on nonwounded plants in ambient (37.0\% plant incidence) and increased humidity conditions $(60.0 \%$ plant incidence). Populations of epiphytic C. michiganensis subsp. nebraskensis survived and increased on maize leaves, particularly at increased humidity. We observed C. michiganensis subsp. nebras kensis colonizing maize leaves in localized sites that included epidermal junctions, cuticle depressions, in and around stomata, and at the base of trichomes. Single cells and aggregates of $C$. michiganensis subsp. nebraskensis were observed within substomatal chambers using SEM. These data indicate that severe wounding is not necessary for $C$. michiganensis subsp. nebraskensis infection of maize, and stomata or trichomes may serve as entry points for the bacterium.
\end{abstract}

Goss's bacterial wilt and leaf blight of maize (Zea mays L.), which is more often referred to as Goss's wilt, is caused by the grampositive bacterium Clavibacter michiganensis subsp. nebraskensis (Vidaver and Mandel 1974). First identified in 1969 in Dawson County, Nebraska (Schuster 1972; Claflin 1999), the disease has been reported in several states throughout the United States as well as Canada (Friskop et al. 2014; Hollier et al. 2014; Jackson et al. 2007; Langemeier 2012; Malvick et al. 2010; Robertson and Jesse 2008; Ruhl et al. 2009; Strunk 2012). Yield losses as high as 40 to $60 \%$ were reported prior to availability of $C$. michiganensis subsp. nebraskensis-resistant dent maize hybrids introduced in the early 1980s (Claflin et al. 1978). In 2012, 50\% yield loss on susceptible hybrids grown in Iowa was observed (A. E. Robertson, unpublished data).

As the name suggests, the disease has two phases. The wilt phase usually occurs in young plants, prior to crop developmental stage V8 (Abendroth et al. 2011), while the leaf blight phase is more common in older plants. Typical leaf symptoms of infection on maize are large, tan to gray, oval lesions with wavy margins. Small, water-soaked spots known as "freckles" found on the periphery of enlarging lesions are characteristic of the disease. An orange exudate on symptomatic leaves can occur during periods of high humidity and dry to a glossy sheen (Jackson et al. 2007). Although uncommon, C. michiganensis subsp. nebraskensis colonization of the leaves can become systemic, resulting in wilt of older plants.

C. michiganensis subsp. nebraskensis-infested surface residue is the primary source of inoculum for Goss's wilt (Jackson et al. 2007). Infection by the bacterium occurs through wounds on the leaves

Corresponding author: A. E. Robertson; E-mail: alisonr@iastate.edu

Accepted for publication 25 October 2015.

http://dx.doi.org/10.1094/PDIS-08-15-0923-RE

(C) 2016 The American Phytopathological Society caused by strong winds, blowing sand, or hail associated with severe storms (Jackson et al. 2007). In Iowa maize fields however, Goss's leaf blight symptoms have been observed developing from the tips of leaves and progressing downward on leaves with no obvious physical injury (Fig. 1) These symptoms are often observed at or soon after the crop is tasseled (A. E. Robertson, unpublished data). These observations suggest that infection may occur through natural openings or superficial wounds on leaves.

Smidt and Vidaver (1986) recovered C. michiganensis subsp. nebraskensis in the field on symptomless leaves of young popcorn and dent maize hybrid plants (approximately 4 weeks after planting) and suggested an epiphytic phase for this pathogen. A few years earlier, while monitoring epiphytic populations of $C$. michiganensis subsp. nebraskensis on susceptible and resistant popcorn hybrids in a greenhouse study, Schuster et al. (1983) observed characteristic leaf blight symptoms of Goss's wilt in the absence of injury. They did not report incidence or severity data but suggested that $C$. michiganensis subsp. nebraskensis could colonize leaf surfaces and infect maize through stomata. They also suggested that infections of leaf tips and margins that were observed in the field in the absence of visible injury arose from infection via epiphytic $C$. michiganensis subsp. nebraskensis. In a follow-up study on six hybrids of maize that varied in susceptibility to Goss's wilt, Schuster et al. (1984) reported infection on all hybrids in the absence of injury ranging from 1.58 to 3.07 on a numerical scale where $1=$ no infection and $5=$ very severe or dead. It is not clear from their study whether a control (noninoculated or mock-inoculated) was included, and no statistics were associated with the data.

There are numerous examples in the literature of infection of host plants via natural openings such as stomata and hydathodes (which are modified stomata) (Huang 1986). On maize, stomata were demonstrated to be the site of ingress of Pseudomonas avenae subsp. avenae (Manns 1909), which causes bacterial leaf blight and stalk rot (Gitaitis 1979; Gitaitis et al. 1981; Schaad et al. 2008; Willems et al. 1992). For the closely related bacterium, $C$. michiganensis subsp. michiganensis, 
hydathodes serve as infection courts for epiphytic colonies of the pathogen on tomato (Carlton et al. 1998; Sharabani et al. 2013).

In addition, bacterial infection may also occur through injuries, including microscopic injuries such as broken trichomes (Huang 1986). For example, populations of $P$. syringae pv. tomato multiplied at the base of trichomes and eventually elicited necrotic symptoms (Bashan et al. 1981). Because adult maize leaves have trichomes (Poethig 1990), it is possible that epiphytic $C$. michiganensis subsp. nebraskensis may colonize these structures and infect via the base. Little is known about how and where epiphytic populations of $C$. michiganensis subsp. nebraskensis colonize maize leaves but, based on our knowledge of other pathosystems, it is conceivable that the pathogen could be associated with stomata or trichomes that, in turn, could serve as potential infection courts.

Light, fluorescent, and electron microscopy have been used to directly observe the infections courts of numerous bacterial plant pathogens (Bogs et al. 1998; Huang 1986), including C. michiganensis subsp. michiganensis (Carlton et al. 1998; Chalupowicz et al. 2012; Lelis et al. 2014). Visualizing infection processes of bacterial pathogens contributes to our understanding of the pathogen-host interaction and often provides new insights that may enable development of novel or improved disease management practices.

In this study, greenhouse experiments were conducted to study Goss's wilt development in the absence of wounding from epiphytic populations of $C$. michiganensis subsp. nebraskensis. Scanning electron microscopy (SEM) was also used to visualize sites of epiphytic colonization and infection of maize leaves. The objectives of this research were to (i) determine whether Goss's wilt can develop in the absence of wounding by way of epiphytic populations of C. michiganensis subsp. nebraskensis on leaves, (ii) visualize colonization of the surface of maize leaves by epiphytic $C$. michiganensis subsp. nebraskensis, and (iii) determine whether epiphytic populations of C. michiganensis subsp. nebraskensis are associated with potential sites of infection such as stomata or trichomes.

\section{Materials and Methods}

Plant material and plant growth conditions. The following experiments were conducted in 2013 in the Iowa State Plant Pathology and Microbiology greenhouse using the $C$. michiganensis subsp. nebraskensis-susceptible hybrid 'Agrigold 6309' (AG6309; rated 2 on a 0 -to- 10 scale, where $1=$ susceptible and $10=$ highly tolerant). Seed were sown in a soil mix consisting of peat moss-metro mix-coarse perlite (4:3:4) in 25 -cm pots (1 seed/pot). Pots were watered daily at the base of each plant to avoid cross contamination of plants by splashing. All plants were fertilized once a week with a liquid fertilizer (NPK 15-5-15, Miracle Gro; The Scotts Co., Marysville, $\mathrm{OH}$ ). Beginning at 2 weeks after planting, the liquid fertilizer was supplemented with the micronutrients $\mathrm{Ca}\left(\mathrm{NO}_{3}\right)_{2}$ and $\mathrm{MgSO}_{4}$ at a rate of 43 and $22 \mathrm{~g} \mathrm{liter}^{-1}$, respectively. The average temperature in the greenhouse was $27 \pm 6^{\circ} \mathrm{C}$. Inoculation occurred when plants reached the V5 crop developmental stage (Abendroth et al. 2011).

Plant inoculation and incubation conditions. Inoculum was produced using a rifampicin-tolerant strain of $C$. michiganensis subsp. nebraskensis, R-91 (C. Block, United States Department of Agriculture Plant Introduction Station, Ames, IA), that had been stored on silica gel at $4^{\circ} \mathrm{C}$. Start-up cultures were obtained by sprinkling a few silica gel pellets onto nutrient broth yeast agar (NBY), containing $8 \mathrm{~g}$ of nutrient broth, $2 \mathrm{~g}$ of yeast extract, $2 \mathrm{~g}$ of $\mathrm{K}_{2} \mathrm{HPO}_{4}, 0.4 \mathrm{~g}$ of $\mathrm{KH}_{2} \mathrm{PO}_{4}$, $0.25 \mathrm{~g}$ of $\mathrm{MgSO}_{4} \mathrm{O} \cdot 7 \mathrm{H}_{2} \mathrm{O}, 5 \mathrm{~g}$ of D-glucose, and $15 \mathrm{~g}$ of agar in a liter of water (Vidaver 1967). Plates were incubated at $25^{\circ} \mathrm{C}$ for 5 days, and single colonies were streaked onto fresh NBY plates for generating inoculum. Bacterial cells were harvested by flooding each plate of a 5-day-old culture with $5 \mathrm{ml}$ of phosphate-buffered saline (PBS) solution ( $\mathrm{pH} 7.0)$. The inoculum concentration of the resultant bacterial suspension was adjusted to an optical density of 0.4 at $600 \mathrm{~nm}$ (approximately $10^{8}$ cells $\mathrm{ml}^{-1}$ ) (Mbofung et al. in press). The suspension was kept at $4^{\circ} \mathrm{C}$ and used within an hour to spray inoculate plants. Negative control plants were sprayed with PBS alone (mock inoculated)

Three experiments were done in February, March, and May 2013, and each experiment was arranged in a randomized complete block design with five replications (4 plants/replication for a total of 20 plants/treatment). In all, 10 plants of each treatment were set aside for destructive sampling for epiphytic $C$. michiganensis subsp. nebraskensis population counts. The remaining 10 plants were rated for Goss's leaf blight disease incidence.

The experiment consisted of four treatments of 20 plants each. Treatment $1=$ mock-inoculated plants kept at ambient humidity conditions (approximately 10 to 30, 12 to 25, and 40 to 60\% in February, March, and May, respectively; negative control), treatment $2=$ inoculated plants kept at ambient humidity conditions, treatment $3=$ inoculated plants immediately placed into increased humidity conditions (20 to $40 \%$ higher than ambient relative humidity [RH]) for $12 \mathrm{~h}$, and treatment $4=$ plants inoculated and wounded on the second leaf

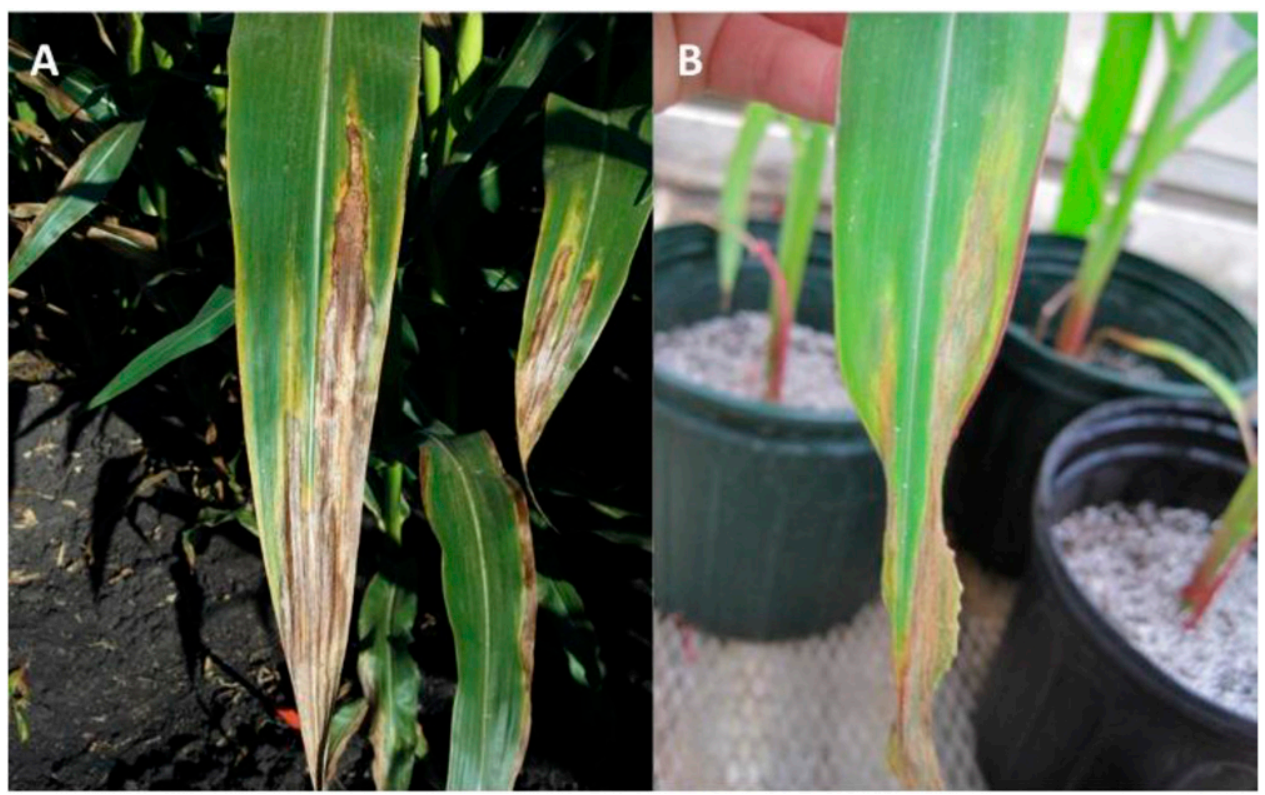

Fig. 1. Symptoms of Goss's leaf blight developing from the tips and progressing toward the stalk on leaves with no obvious physical injury A, on a maize plant in a commercial field in lowa and $\mathbf{B}$, on unwounded maize plants inoculated by spraying a suspension of Clavibacter michiganensis subsp. nebraskensis $\left(10^{8} \mathrm{CFU} \mathrm{ml^{-1 }}\right)$ in the greenhouse. 
using the pinprick inoculation technique (Blanco et al. 1977; Calub et al. 1974) and placed at ambient humidity conditions (positive control). Twelve hours prior to inoculation, pots in the increased humidity treatments were put on a plastic tray and the soil in each pot was completely saturated with water. Chambers for generating higher humidity conditions were created out of cardboard boxes measuring 46 by 61 by $61 \mathrm{~cm}$, five plants per box (Home Depot Model number 906058; Home Depot, Atlanta, GA), with windows cut out on each side of the chamber to allow light to pass through. The chambers were lined internally with clear plastic wrap (cling wrap; Glad, Oakland, CA) to insulate and conserve humidity.

Maize plants were inoculated in the morning hours (7:00 to 10:00 A.M.) using a Sure-Shot sprayer air gun (448 kPa, cone-jet tvx-3 nozzle; Milwaukee Sprayer, Menomonee Falls, WI). Approximately $10 \mathrm{ml}$ of inoculum suspension per plant was applied to whole plants until all leaves were covered with a thin film of inoculum suspension. Before inoculation, control plants were removed from the room, sprayed with PBS buffer, and returned after the bacterial suspension had dried on the inoculated plants.

Data collection. The presence or absence of Goss's leaf blight lesions on each leaf of each plant was assessed four times at 7, 10, 13, and 17 days after inoculation (DAI) in experimental run 1 in February. In experimental run 2 in March, assessments were made 7, 10, 13, and $21 \mathrm{DAI}$ and, in experimental run 3 in May, assessments were made $7,10,13,17$, and 21 DAI.

In order to evaluate changes in epiphytic $C$. michiganensis subsp. nebraskensis populations over time, the second (V2) and third (V3) leaves of two plants in each treatment were sampled at 2, 12, 24, 72, and $168 \mathrm{~h}$ after inoculation (HAI). In the positive control treatment (plants wounded immediately after inoculation), V2 and V3 leaves were either symptomatic or dead at $168 \mathrm{HAI}$; therefore, V4 and V5 leaves were sampled. At each time point, a piece of asymptomatic green leaf tissue approximately 5 to $8 \mathrm{~cm}$ in length $(0.5$ to $2.0 \mathrm{~g})$ was sampled close to the leaf tip, weighed, and placed in a sterile Pyrex test tube containing $20 \mathrm{ml}$ of wash buffer $(0.1 \mathrm{M}$ potassium phosphate buffer, $\mathrm{pH} 7$, containing $0.1 \%$ peptone). Tubes were sonicated $7 \mathrm{~min}$ in a B200 ultrasonic cleaning bath (Branson Ultrasonics Corp., Danbury, CT) filled with cold water, then vortexed for $15 \mathrm{~s}$ (Beattie and Marcell 2002; Sharabani et al. 2013). Two 10-fold dilutions $\left(10^{-1}\right.$ and $\left.10^{-2}\right)$ of the original suspension were made with PBS buffer, then were plated on NBY medium amended with rifampicin $\left(100 \mu \mathrm{g} \mathrm{ml}^{-1}\right)$. Sterile glass beads were used to spread each aliquot across the medium surface. Plates were incubated at $25^{\circ} \mathrm{C}$ for 6 to 9 days, after which $\mathrm{CFU}$ were counted. The population sizes were expressed as CFU per gram of fresh leaf tissue. An estimate of the mean population of $C$. michiganensis subsp. nebraskensis at each time point was determined ( $\left.\log _{10} \mathrm{scale}\right)$.

SEM. SEM was used to visualize colonization of nonwounded maize leaves and the association of C. michiganensis subsp. nebraskensis with possible infection courts. Inoculations with R-91 were done as described above and plants were immediately placed in humidity chambers for $12 \mathrm{~h}$.

Twenty seeds of maize hybrid Agrigold 6309 were grown to the V4 to V5 crop developmental stage. Whole plants were spray inoculated as described above and immediately placed in an humidity chamber for $12 \mathrm{~h}$, after which they were removed and placed on the greenhouse bench under ambient conditions. Control plants were sprayed with PBS buffer.

To observe colonization of the leaf surface by $C$. michiganensis subsp. nebraskensis, 10 plants were sampled for SEM. A completely randomized design with five replications was used. Three to five leaf tissue samples (45 to $100 \mathrm{~mm}^{2}$ ) were cut 2 to $5 \mathrm{~cm}$ from the tip and very close to the edge of leaves 3 and 4 at 12 and 72 HAI, immediately fixed in formalin-acetic acid-alcohol (FAA; Jensen 1962), and stored at $4^{\circ} \mathrm{C}$ for further processing.

To narrow down the sampling area and increase the probability of observing C. michiganensis subsp. nebraskensis in association with potential infection courts, brass drapery rings $(9.5 \mathrm{~mm}$ in diameter; Wawak Sewing Co., Conklin, NY) were secured with the aid of a film of an inert silicon-based grease (Dow Corning high-vacuum grease; Dow Corning Corporation, Midland, MI) on the upper surface of 20 arbitrarily selected leaves at $2.5 \mathrm{~cm}$ from the leaf tip (one ring per plant). Inoculum suspension $(1 \mathrm{ml})$ containing approximately $10^{8}$ cells of $C$. michiganensis subsp. nebraskensis was placed in the inner surface of the ring. The inoculum dried on the surface of the leaf within 1 to $2 \mathrm{~h}$. The leaf areas within the rings were sampled by cutting them out with a cork borer of smaller diameter at 12 and $72 \mathrm{HAI}$, and immediately fixed in FAA and stored at $4^{\circ} \mathrm{C}$ for further processing.

Leaf samples prepared for SEM observation were dehydrated in an ethanol series, starting with $50 \%$ ethanol and finishing in ultrapure ethanol, and dried using liquid carbon dioxide on a DCP-1 critical point dryer (Denton Vacuum, Moorestown, NJ). Leaf fractures were prepared by sandwiching a critical-point-dried sample on doublesided clear tape that was flattened with a hammer and then quickly pulled apart to produce two complementary internal leaf surfaces. These fractured pieces were then mounted internal-side up on a large SEM aluminum plate. All processed samples were sputter coated with a palladium/gold alloy (60/40) using a Denton Desk II Sputter Coater (Denton Vacuum) and imaged using a JEOL 5800LV SEM (Jeol, Peabody, MA) at $13 \mathrm{kV}$.

Data analysis. Goss's wilt incidence at the plant level was determined as the percentage of plants with at least one leaf with a lesion present in a treatment. Goss's wilt incidence at the leaf level was determined as the percentage of leaves with at least one lesion present in a treatment. Analysis of differences between treatments in plant and leaf incidences was accomplished using PROC GLIMMIX in SAS (v. 9.3; SAS Institute, Cary, NC). Initial analyses using experimental run, treatment, and time (DAI) as fixed effects indicated no differences between runs for Goss's wilt plant and leaf incidences. Therefore, all experiments were combined for analyses; the level of significance was set to $5 \%(\alpha=0.05)$. Area under the disease progress curves (AUDPC) (Campbell and Madden 1990; Simko and Piepho 2012) was calculated using leaf incidence. Treatment differences of the AUDPC values were detected using PROC MIXED in SAS. Orthogonal contrasts were used to test treatment differences in final plant and leaf incidence AUDPC.

Changes in mean C. michiganensis subsp. nebraskensis population density over time and mean population densities averaged across all sampling periods were compared using PROC MIXED. Combined analysis was done to increase the sampling size through replication and, more importantly, to compare the effects of treatments over experiments (environments). Treatment and sampling period (HAI) were considered fixed effects while experiment, plant, and leaf were handled as random effects. Mean population densities were calculated based on all data points, including those with zero titers, and also as means for nonzero data points. The means for nonzero data points were graphed. Orthogonal contrasts were used to test treatment differences in mean C. michiganensis subsp. nebraskensis population densities across sampling times. Relationships between Goss's wilt plant incidence and mean epiphytic $C$. michiganensis subsp. nebraskensis population density were assessed using Pearson's correlation analysis and, because no relationships were found, no further relationships were examined.

\section{Results}

Disease incidence. At the plant level, treatment differences in Goss's leaf blight incidence were detected $(P<0.0001)$ (Table 1$)$. Plants that were inoculated and kept under ambient humidity conditions had lower incidence of symptomatic plants (37.0\% incidence) compared with plants in the increased humidity treatments $(60.0 \%$ incidence). No disease developed in the negative (mock-inoculated) control treatment, while all plants in the positive (inoculated, then wounded) control treatment were symptomatic on the final assessment date.

Plants with typical Goss's leaf blight lesions were first observed 7 DAI in the inoculated wounded treatment (positive control) and the inoculation and increased humidity treatment (96.7 and 10\%, respectively; Fig. 2). In the inoculation and ambient humidity treatment, symptoms were first observed a few days later (10 DAI). On subsequent observation dates, the number of symptomatic plants in all inoculated treatments increased over time. Leaf blight lesions started from the tip or edge of the leaf and extended down the leaf toward the leaf sheath over time (Fig. 1). 
Effect of inoculation was tested on the incidence of disease at the leaf level (leaf incidence; Table 1). The highest incidence of symptomatic leaves was observed on inoculated and wounded plants

Table 1. Final mean incidence of plants and leaves with Goss's bacterial wilt and leaf blight (GWLB) symptoms, and area under the disease progress curve (AUDPC) of a susceptible maize hybrid, AG6309

\begin{tabular}{|c|c|c|c|}
\hline Treatment $^{\mathbf{a}}$ & $\begin{array}{c}\text { Plant } \\
\text { incidence } \\
(\%)^{\mathbf{b}}\end{array}$ & $\begin{array}{c}\text { Leaf } \\
\text { incidence } \\
(\%)^{\mathbf{c}}\end{array}$ & AUDPC $^{d}$ \\
\hline $1=$ Noninoculated, ambient $\mathrm{RH}$ & 0.0 & 0.0 & 0.00 \\
\hline 2 = Inoculated, ambient RH & 37.0 & 13.3 & 0.04 \\
\hline 3 = Inoculated, high RH & 60.0 & 33.3 & 0.15 \\
\hline 4 = Inoculated, wounded & 100.0 & 51.8 & 0.26 \\
\hline$P$ value & $<0.0001$ & $<0.0001$ & $<0.0001$ \\
\hline \multicolumn{4}{|l|}{ Contrasts $^{\mathrm{d}}$} \\
\hline $\begin{array}{l}\text { Treatment } 1 \text { vs. treatment } 2 \text {, } \\
P \text { value }\end{array}$ & $<0.0001$ & 0.0012 & 0.0733 \\
\hline $\begin{array}{l}\text { Treatment } 2 \text { vs. treatment } 3 \text {, } \\
P \text { value }\end{array}$ & $<0.0001$ & $<0.0001$ & $<0.0001$ \\
\hline $\begin{array}{l}\text { Treatment } 3 \text { vs. treatment } 4, \\
P \text { value }\end{array}$ & $<0.0001$ & $<0.0001$ & $<0.0001$ \\
\hline
\end{tabular}

a Maize plants at the V4 to V5 crop development stage were inoculated by spraying a suspension of Clavibacter michiganensis subsp. nebraskensis $\left(10^{8} \mathrm{CFU} \mathrm{m}{ }^{-1}\right)$ until the leaves were covered in a thin film of inoculum. $\mathrm{RH}=$ relative humidity.

b Plant incidence was calculated from the number of plants with GWLB symptoms $(n=10)$.

${ }^{c}$ Leaf incidence was calculated as the percent of all leaves with GWLB symptoms.

d AUDPC was calculated from leaf incidence data.
(51.8\%), followed by plants exposed to high humidity after inoculation $(33.3 \%)$ and the plants exposed to ambient humidity after inoculation (13.3\%). Leaf incidence increased over time in these three treatments (Fig. 3). AUDPC based on leaf incidence data also differed among inoculation treatments $(P<0.0001$; Table 1). The AUDPC values for plants inoculated and kept under ambient (low) humidity were not different from those of noninoculated control plants $(P=0.0733)$. Plants exposed to increased RH immediately after inoculation had a greater AUDPC value (0.15) compared with plants that were inoculated and kept under ambient (low) humidity conditions $(0.04)(P<$ $0.0001)$ but this AUDPC value was lower than that of the positive control $(0.26)(P<0.0001)$.

Epiphytic colonization. Epiphytic population data from all three experimental runs were analyzed together. Differences among inoculation treatments were detected $(P<0.0001)$. The pathogen was only detected in leaf washes from inoculated leaves (Fig. 4), and the frequency of $C$. michiganensis subsp. nebraskensis-positive leaf samples, which ranged from 75 to $100 \%$ at each sampling time, was always highest (100\%) from leaves of inoculated and wounded plants (data not shown).

At 2 HAI, no differences in the populations of $C$. michiganensis subsp. nebraskensis in each treatment were observed (Fig. 4). The populations in all treatments declined between 12 and 24 HAI but, thereafter, they steadily increased over the course of the experiment. Mean epiphytic $C$. michiganensis subsp. nebraskensis population densities were lowest at 24, 72, and $168 \mathrm{HAI}$ on plants that were exposed to ambient humidity conditions after inoculation compared with population densities on plants of the other two treatments. Mean population densities in the inoculated and wounded plants were higher than those recovered from plants that were inoculated and then exposed to increased RH at 72 and $168 \mathrm{HAI}$.

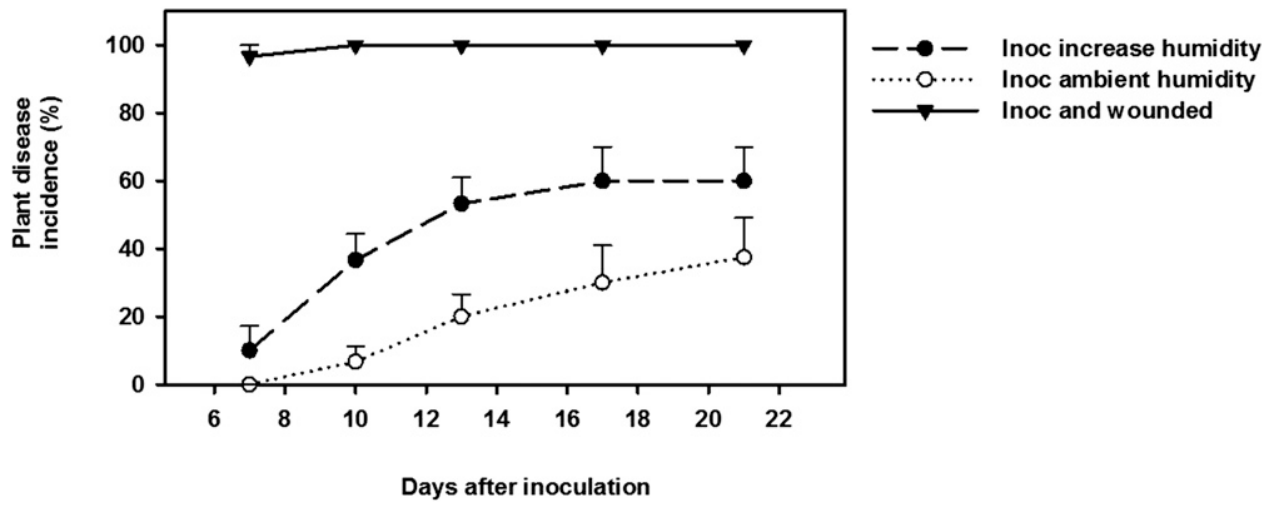

Fig. 2. Mean plant incidence of Goss's leaf blight of a susceptible maize hybrid (AG6309) following inoculation with Clavibacter michiganensis subsp. nebraskensis (10 ${ }^{8} \mathrm{CFU}$ ml ${ }^{-1}$ ) at the V5 crop developmental stage.

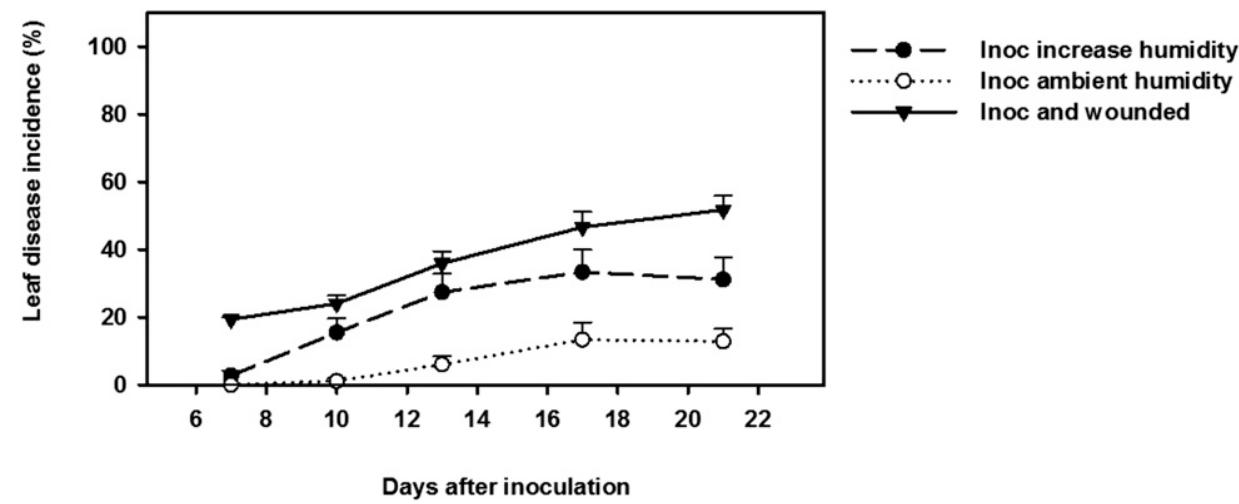

Fig. 3. Mean leaf incidence of Goss's leaf blight of a susceptible maize hybrid (AG6309) spray inoculated with Clavibacter michiganensis subsp. nebraskensis $\left(10^{8} \mathrm{CFU} \mathrm{ml}^{-1}\right)$ at the V5 crop developmental stage. 
Visualization of colonization on maize leaves by $C$. michiganensis subsp. nebraskensis. At $12 \mathrm{~h}$ after spray inoculation, single cells and aggregates of $C$. michiganensis subsp. nebraskensis cells were occasionally observed on the stomata and around the guard cells (Fig. 5). Cells and aggregates of $C$. michiganensis subsp. nebraskensis were frequently observed scattered over the leaf surface, particularly around trichome bases and cuticle depressions, along the veins, and at epidermal cell junctions.

SEM imagery of leaf surfaces within rings prepared $12 \mathrm{HAI}$ showed more $C$. michiganensis subsp. nebraskensis cells present on the leaf surface in similar locations observed when the leaves were spray inoculated with the bacterium. With the ring method of inoculation, however, C. michiganensis subsp. nebraskensis cell aggregates were more frequently observed on guard cells, around the edge of stomata, and within stomata openings (Fig. 6). Furthermore, C. michiganensis subsp. nebraskensis cells were observed within the substomatal chambers in tissues sampled at $72 \mathrm{HAI}$. Leaf fractures exposed mesophyll cells with rows of substomatal chambers (Fig. 6 ), within which we observed single cells or aggregates of $C$. michiganensis subsp. nebraskensis.

\section{Discussion}

In this study, we used replicated greenhouse studies and showed that Goss's wilt developed in the absence of wounding from an epiphytic source of C. michiganensis subsp. nebraskensis. Using SEM, we observed $C$. michiganensis subsp. nebraskensis colonizing sheltered areas of the leaf surface (cuticle depressions, along the veins, and at epidermal cell junctions) and in association with stomata and the base of trichomes.

In the first $24 \mathrm{HAI}$, we detected a decline in epiphytic $C$. michiganensis subsp. nebraskensis populations on leaves; however, thereafter, we detected a steady increase in the $C$. michiganensis subsp. nebraskensis

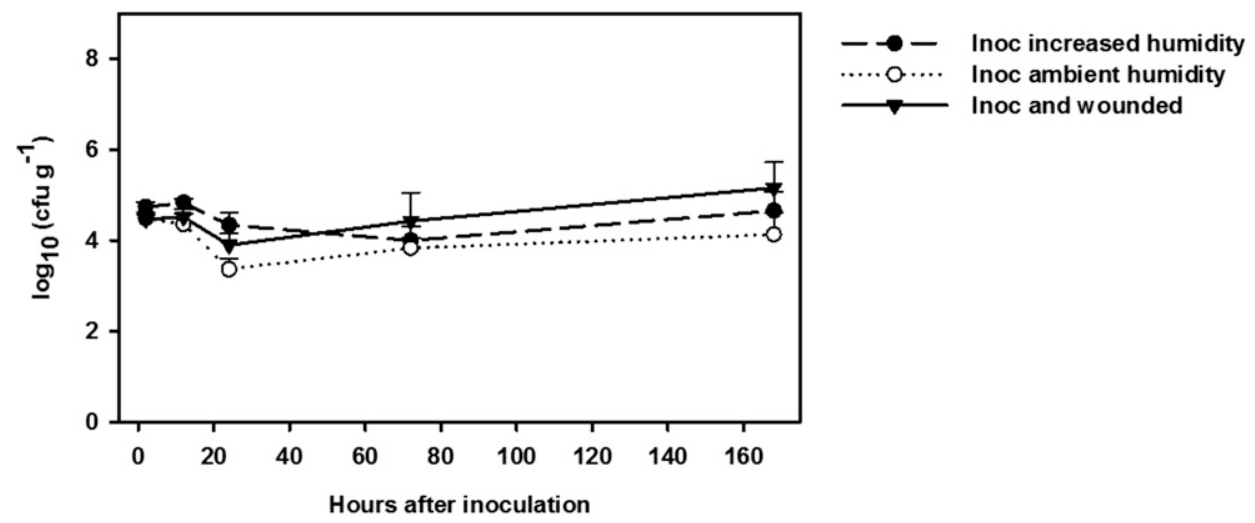

Fig. 4. Mean epiphytic population densities of Clavibacter michiganensis subsp. nebraskensis detected on leaves sampled from a susceptible maize hybrid (AG6309) after spray inoculation of the pathogen $\left(10^{8} \mathrm{CFU} \mathrm{ml}{ }^{-1}\right)$.
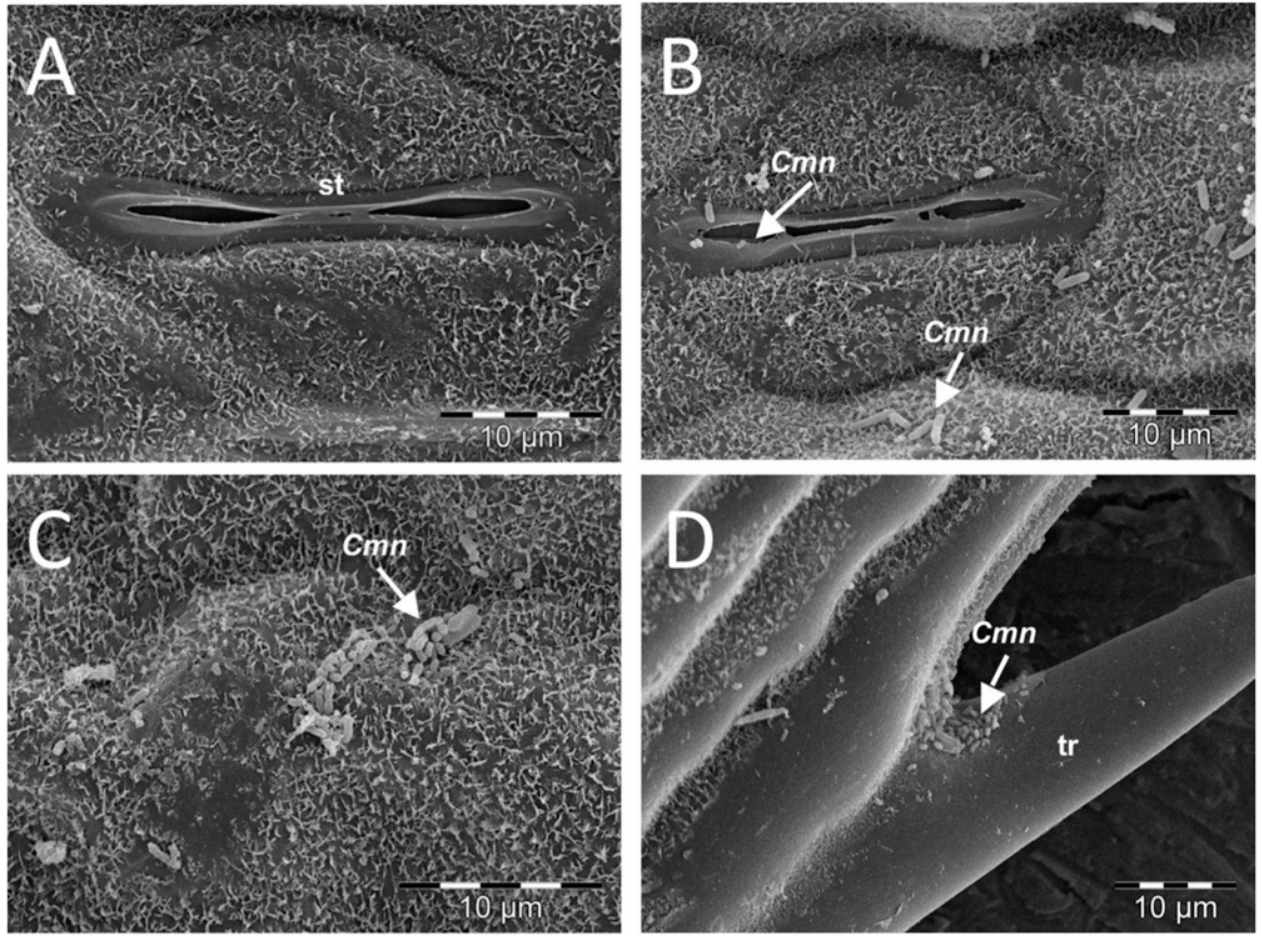

Fig. 5. Scanning electron microscopy images of maize leaves $12 \mathrm{~h}$ after spray inoculation with Clavibacter michiganensis subsp. nebraskensis $\left(10^{8} \mathrm{CFU} \mathrm{ml}{ }^{-1}\right)$. A, Representative stoma (st) on a noninoculated leaf; no bacterial cells were detected on the stoma or elsewhere on the leaf surface; $B$, several solitary $\mathbf{C}$. michiganensis subsp. nebraskensis cells $(\mathrm{Cmn})$ and aggregates of $\mathrm{C}$. michiganensis subsp. nebraskensis detected on the lip of and around a stoma of inoculated maize leaf; $\mathbf{C}, \boldsymbol{C}$. michiganensis subsp. nebraskensis cells $(\mathrm{Cmn})$ colonizing epidermal cell junctions and depressions in the leaf cuticle; and D, C. michiganensis subsp. nebraskensis cells ( $\mathrm{Cmn}$ ) and aggregates at the base of a trichome (tr). 
population on the leaf surface over time. Marcell and Beattie (2002) observed a similar decline in the first $24 \mathrm{HAI}$, followed by increasing C. michiganensis subsp. nebraskensis population density. Increased $\mathrm{RH}$ aided survival and population growth of $C$. michiganensis subsp. nebraskensis on the leaf surface because larger populations of C. michiganensis subsp. nebraskensis were detected throughout the experiment on plants that were inoculated and immediately placed in humidity chambers for $12 \mathrm{~h}$. Plant-pathogenic bacteria survive better and populations are more abundant in high-humidity conditions (Griffin and Carson 2015; Monier and Lindow 2004). In addition, Leben (1988) reported that higher humidity resulted in greater infection rates by $P$. syringae on cucumber. Thus, the higher humidity and larger populations of $C$. michiganensis subsp. nebraskensis we detected probably contributed to the greater Goss's wilt incidence that we noted in our inoculated, increased-humidity treatment compared with the inoculated, ambient-humidity treatment.
In the current study, lesion development on spray-inoculated, nonwounded plants in the greenhouse was similar to that observed in the field in Iowa on apparently nonwounded plants, in that lesions developed from the tips and edges of leaves (Fig. 1). Stomata on maize leaves occur along the edge of the leaf and also in rows parallel to the leaf veins (Croxdale 2000; Driscoll et al. 2006). We propose that infection may occur through stomata or other natural openings or indiscernible wounds on maize leaves. Using SEM, we observed cells and aggregates of $C$. michiganensis subsp. nebraskensis associated with some stomata, in some substomatal chambers, and at the base of trichomes. We saw no evidence of wounding (cuts or tears) in the leaf surface.

Stomata are usually open under high-humidity conditions (Loftfield 1921; Zheng et al. 2013). Thus, our treatment with higher humidity likely resulted in more open stomata. Because we detected higher epiphytic populations, the higher disease incidence we observed might
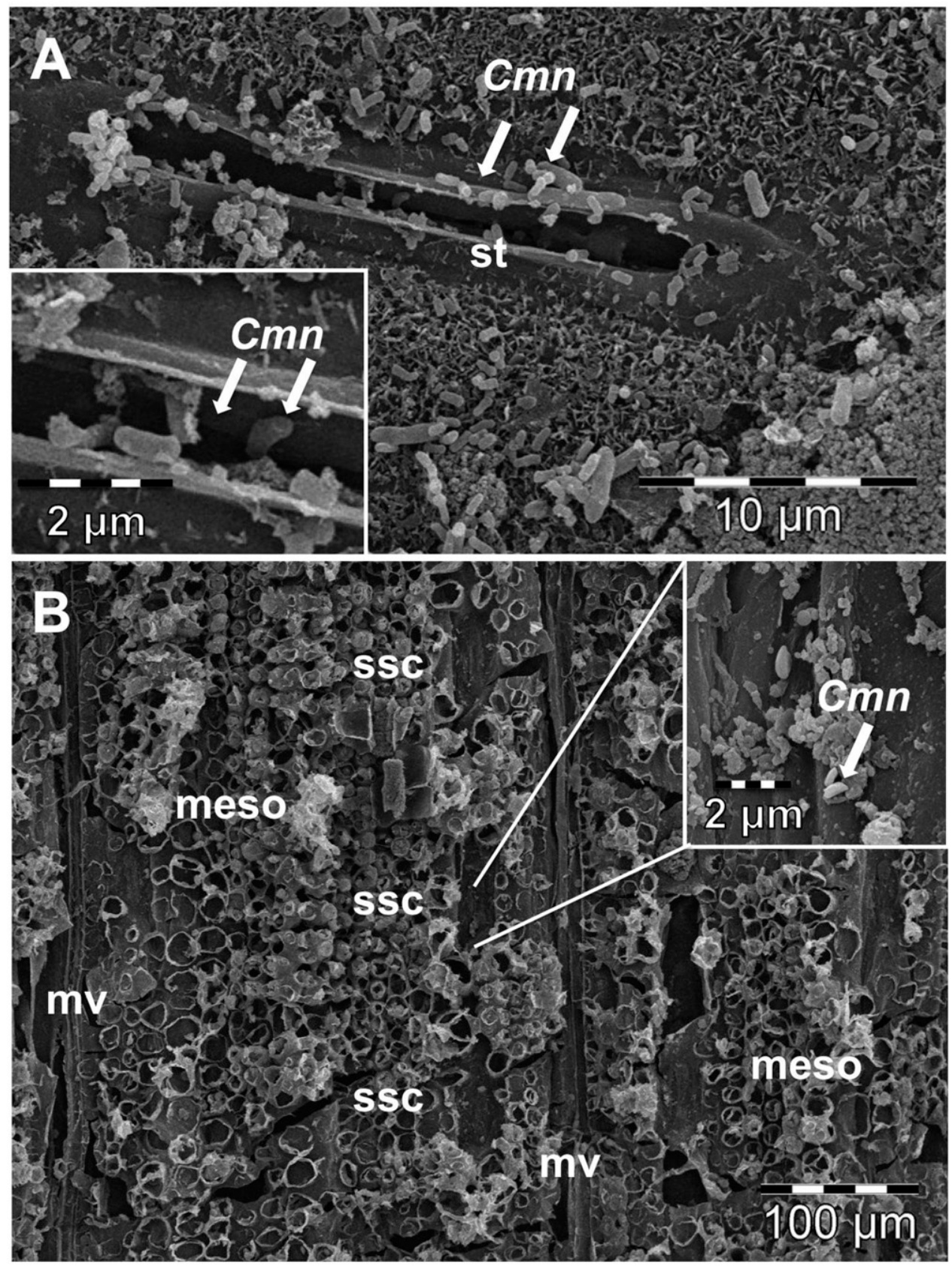

Fig. 6. Scanning electron microscopy images of maize leaf fractures prepared $72 \mathrm{~h}$ after a suspension of Clavibacter michiganensis subsp. nebraskensis $\left(10^{8} \mathrm{CFU} \mathrm{ml}^{-1}\right)$ was placed in a confined area on the leaf surface. A, Individual bacterial cells and aggregates of $\mathbf{C}$. michiganensis subsp. nebraskensis (Cmn) observed on, within. and around a stoma (st) on the surface of an inoculated maize leaf. Inset: C. michiganensis subsp. nebraskensis cells observed within the stoma. B, Mesophyll cells with organelles, row of substomatal chambers (ssc), and major veins (mv). Inset: C. michiganensis subsp. nebraskensis bacterial cells within a substomatal chamber. 
also be explained by a greater chance of infection via stomata. Sharon et al. (1982) reported that even small numbers of Xanthomonas campestris pv. vesicatoria, located in advantageous sites on bell pepper leaf surfaces, could multiply under conducive conditions, enter leaves through stomata, and eventually cause disease.

Using the spray-inoculation method, more often than not, we observed single cells of $C$. michiganensis subsp. nebraskensis scattered over the leaf surface and, less frequently, single bacterial cells associated with stomata. Because $C$. michiganensis subsp. nebraskensis does not possess any motile structures and, therefore, is immobile on the leaf surface, landing on the lip of a stoma is likely to be a fortuitous event. When nonwounded sweet corn leaves were inoculated with $P$. avenae subsp. avenae without wounding, typical lesions of bacterial leaf blight were observed (Gitaitis et al. 1981). To observe ingress through stomata, Gitaitis et al. (1981) inoculated sweet corn leaves with $10^{9}$ cells ml $\mathrm{m}^{-1}$ and, approximately $5 \mathrm{~h}$ later, they reported observing bacterial cells within substomatal chambers using SEM. Based on these data, they suggested that stomata were the point ingress for the pathogen. Similarly, in our study, we applied a suspension of C. michiganensis subsp. nebraskensis $\left(10^{8} \mathrm{CFU} \mathrm{ml^{-1 }}\right)$ to a confined area of the leaf surface using a ring inoculation method. This was done to increase our chances of observing the $C$. michiganensis subsp. nebraskensis in substomatal chambers because we were looking in a known area of $C$. michiganensis subsp. nebraskensis-inoculated leaf tissue. Using this method, we observed $C$. michiganensis subsp. nebraskensis cells in substomatal chambers at 72 HAI.

We often observed aggregates of $C$. michiganensis subsp. nebraskensis associated with trichomes on the edge of the leaf. Bashan et al. (1981) observed extensive multiplication of $P$. syringae pv. tomato at the base of trichomes. Their work suggested that bacteria in this area are the primary source of inoculum for bacterial speck, and that trichomes are target sites for infections. We occasionally observed broken trichomes on the maize leaf samples we collected in our microscopic studies. It is not clear from our studies whether trichomes (broken or not) may also serve as a site of ingress for C. michiganensis subsp. nebraskensis; however, infection of tomato by epiphytic $C$. michiganensis subsp. michiganensis can occur via broken trichomes (Chang et al. 1992; Gleason et al. 1993). Further work is needed to explore whether epiphytic $C$. michiganensis subsp. nebraskensis preferentially colonizes maize leaves at the bases of trichomes, and whether this area is a site of infection for the pathogen.

In conclusion, our greenhouse studies demonstrate that Goss's wilt can develop in the absence of severe wounding. In addition, we present data that $C$. michiganensis subsp. nebraskensis survives and proliferates on maize leaves, and microscopic observations show the bacteria colonizing sheltered areas on the leaf. Furthermore, our SEM suggests that stomata, or trichomes on the edge of leaves, may serve as infection courts for epiphytic $C$. michiganensis subsp. nebraskensis populations. These insights into the interaction of C. michiganensis subsp. nebraskensis with maize further our understanding of this economically important pathosystem. Further research is needed, however, to assess the role of epiphytic $C$. michiganensis subsp. nebraskensis and infection routes of the bacterium in the development of Goss's wilt in field conditions.

\section{Acknowledgments}

This research was partially supported by funds from the United States Department of Agriculture NC IPM grant number 2011-34103-30714. We thank T. Stewart and H. T. Horner of the Microscopy and Nanoimaging Facility, Iowa State University, for assistance in setting up experiments and preparing samples intended for scanning electron microscopy; and the Agrigold Seed Co. for providing seed.

\section{Literature Cited}

Abendroth, L. J., Elmore, R. W., Boyer, M. J., and Marlay, S. K. 2011. Corn growth and development. PMR 1009. Iowa State Univ. Extension. Ames, IA.

Bashan, Y., Sharon, E., Okon, Y., and Henis, Y. 1981. Scanning electron and light microscopy of infection and symptom development in tomato leaves infected with Pseudomonas tomato. Physiol. Plant Pathol. 19:139-144, IN1-IN4.

Beattie, G. A., and Marcell, L. M. 2002. Comparative dynamics of adherent and non-adherent bacterial populations on maize leaves. Phytopathology 92:1015-1023.
Blanco, M. H., Johnson, M. G., Colbert, T. R., and Zuber, M. S. 1977. An inoculation technique for Stewart's wilt disease of corn. Plant Dis. Rep. 61: 413-416.

Bogs, J., Bruchmüller, I., Erbar, C., and Geider, K. 1998. Colonization of host plants by the fire blight pathogen Erwinia amylovora marked with genes for bioluminescence and fluorescence. Phytopathology 88:416-421.

Calub, A. G., Schuster, M. L., Compton, W. A., and Gardner, C. O. 1974 Improved technique for evaluating resistance of corn to Corynebacterium nebraskense. Crop Sci. 14:716-718.

Campbell, C. L., and Madden, L. V. 1990. Introduction to Plant Disease Epidemiology. John Wiley \& Sons, New York.

Carlton, W. M., Braun, E. J., and Gleason, M. L. 1998. Ingress of Clavibacter michiganensis subsp. michiganensis into tomato leaves through hydathodes. Phytopathology 88:525-529.

Chalupowicz, L., Zellermann, E.-M., Fluegel, M., Dror, O., Eichenlaub, R., Gartemann, K.-H., Savidor, A., Sessa, G., Iraki, N., Barash, I., and ManulisSasson, S. 2012. Colonization and movement of GFP-labeled Clavibacter michiganensis subsp. michiganensis during tomato infection. Phytopathology 102:23-31.

Chang, R. J., Ries, S. M., and Pataky, J. K. 1992. Local sources of Clavibacter michiganensis subsp. michiganensis in the development of bacterial canker on tomatoes. Phytopathology 82:553-560.

Claflin, L. E. 1999. Goss's bacterial wilt and blight. Pages 4-5 in: Compendium of Corn Diseases, 3rd ed. D. G. White, ed. American Phytopathological Society, St. Paul, MN.

Claflin, L. E., Bockelman, D. L., Shahin, E. A. and Walter, T. L. 1978. The effect of Corynebacterium nebraskense on corn yields. Phytopathology News $12: 86$.

Croxdale, J. L. 2000. Stomatal patterning in angiosperms. Am. J. Bot. 87: 1069-1080.

Driscoll, S. P., Prins, A., Olmos, E., Kunert, K. J., and Foyer, C. H. 2006 Specification of adaxial and abaxial stomata, epidermal structure and photosynthesis to $\mathrm{CO} 2$ enrichment in maize leaves. J. Exp. Bot. 57: 381-390.

Friskop, A., Kinzer, K., McConnell, M., and Liu, Z. 2014. First Report of Goss's Bacterial Leaf Blight and Wilt of Corn Caused by Clavibacter michiganensis subsp. nebraskensis in North Dakota. Plant Dis. 98:1739.

Gitaitis, R. D. 1979. The ingress of Pseudomonas alboprecipitans Rosen into sweet corn (Zea mays Saccharata (Sturtevant) Bailey) in relation to stomatal aperture and infection court. Ph.D. thesis, University of Florida.

Gitaitis, R. D., Samuelson, D. A., and Strandberg, J. O. 1981. Scanning electron microscopy of ingress and establishment of Pseudomonas alboprecipitans in sweet corn leaves. Phytopathology 71:171-175.

Gleason, M. L., Gitaitis, R. D., and Ricker, M. D. 1993. Recent progress in understanding and controlling bacterial canker of tomato in eastern North America. Plant Dis. 77:1069-1076.

Griffin, E. A., and Carson, W. P. 2015. The ecology and natural history of foliar bacteria with a focus on tropical forests and agroecosystems. Bot. Rev. 81 105-149.

Hollier, C. A., Singh, R. A. and Frazier, R. 2014. Goss's wilt in Louisiana: Incidence, severity and loss. (Abstr.) Phytopathology 104:S2.5.

Huang, J.-S. 1986. Ultrastructure of bacterial penetration in plants. Annu. Rev. Phytopathol. 24:141-157.

Jackson, T. A., Harveson, R. M., and Vidaver, A. K. 2007. Reemergence of Goss's wilt and blight of corn to the central High Plains. Online publication. Plant Health Prog. doi:10.1094/PHP-2007-0919-01-BR

Jensen, W. A. 1962. Botanical Histochemistry. Principles and Practice. W. H. and Co., San Francisco, London.

Langemeier, C. B. 2012. Improved understanding of factors influencing the reemergence of Goss's bacterial wilt and blight of corn. M.S. thesis, University of Nebraska-Lincoln.

Leben, C. 1988. Relative humidity and the survival of epiphytic bacteria with buds and leaves of cucumber plants. Phytopathology 78:179-185.

Lelis, F. M. V., Czajkowski, R., de Souza, R. M., Ribeiro, D. H., and van der Wolf, J. M. 2014. Studies on the colonization of axenically grown tomato plants by a GFP-tagged strain of Clavibacter michiganensis subsp. michiganensis. Eur. J. Plant Pathol. 139:53-66.

Loftfield, J. V. G. 1921. The behaviour of stomata. Publication of the Carnegie Institution of Washington, no. 314:1-104.

Malvick, D., Syverson, R., Mollov, D., and Ishimaru, C. A. 2010. Goss's bacteria blight and wilt of corn caused by Clavibacter michiganensis subsp. nebraskensis occurs in Minnesota. Plant Dis. 94:1064

Marcell, L. M., and Beattie, G. A. 2002. The effect of leaf surface waxes on leaf colonization by Pantoea agglomerans and Clavibacter michiganensis. Mol. Plant-Microbe Interact. 15:1236-1244.

Mbofung, G. Y., Sernett, J., Horner, H. T., and Robertson, A. E. Comparison of susceptible and resistant maize hybrids to colonization by Clavibacter michiganensis subsp. nebraskensis. Plant Dis. In press. doi:10.1094/PDIS-0415-0448-RE

Monier, J.-M., and Lindow, S. E. 2004. Frequency, size, and localization of bacterial aggregates on bean leaf surfaces. Appl. Environ. Microbiol. 70:346-355.

Poethig, R. S. 1990. Phase change and the regulation of shoot morphogenesis in plants. Science 250:923-930. 
Robertson, A. E., and Jesse, L. C. H. 2008. Goss's Wilt Prevalent in Western Iowa. Integrated Crop Management News. Paper 791. http://lib.dr.iastate. edu/cropnews/791

Ruhl, G., Wise, K., Creswell, T., Leonberger, A., and Speers, C. 2009. First report of Goss's bacterial wilt and leaf blight on corn caused by Clavibacter michiganensis subsp. nebraskensis in Indiana. Plant Dis. 93:841.

Schaad N. W., Postnikova, E., Sechler, A., Claflin, L. E., Vidaver, A. K., Jones, J. B., Agarkova, I., Ignatov, A., Dickstein, E. and Ramundo, B. A. 2008. Reclassification of subspecies of Acidovorax avenae as A. avenae (Manns 1905) emend., A. cattleyae (Pavarino, 1911) comb. nov., A. citrulli Schaad et al. 1978. comb. nov. and proposal of A. oryzae sp. nov. Syst. Appl. Microbiol. 31: 434-446.

Schuster, M. L. 1972. Leaf freckles and wilt, a new corn disease. Pages 176-191 in: Proc. 27th Annu. Corn Sorghum Res. Conf. Publ. No. 27. Chicago.

Schuster, M. L., Smith, C. C., and Smith, D. J. 1983. Population trends of epiphytic Corynebacterium nebraskense on leaves of popcorn genotypes. Fitopatol. Bras. 8:237-242.

Schuster, M. L., Smith, C. C., and Ziegelbein, M. 1984. Population trends of epiphytic Corynebacterium nebraskense on leaves of maize genotypes. Fitopatol. Bras. 9:249-253.

Sharabani, G., Shtienberg, D., Borenstein, M., Shulhani, R., Lofthouse, M., Sofer, M., Chalupowicz, L., Barel, V., and Manulis-Sasson, S. 2013. Effects of plant age on disease development and virulence of $C$. michiganensis subsp. michiganensis on tomato. Plant Pathol. 62:1114-1122.
Sharon, E., Okon, Y., Bashan, Y., and Henis, Y. 1982. Detached leaf enrichment: A method for detecting small numbers of Pseudomonas syringae and Xanthomonas campestris pv. vesicatoria in seed and symptomless leaves of tomato and pepper. J. Appl. Bacteriol. 53:371-377.

Simko, I., and Piepho, H. P. 2012. The area under the disease progress stairs (AUDPS) Calculation, advantages, and application. Phytopathology 102:381-389.

Smidt, M., and Vidaver, A. K. 1986. Population dynamics of Clavibacter michiganense subsp. nebraskense in field-grown dent corn and popcorn. Plant Dis. 70:1031-1036.

Strunk, C. 2012. Goss's wilt attacking South Dakota maize fields early. Online publication. IGrow, South Dakota State University Extension. http://igrow. org/agronomy/corn/gosss-wilt-attacking-south-dakota-corn-fields-early/

Vidaver, A. K. 1967. Synthetic and complex media for rapid detection of fluorescence of phytopathogenic pseudomonads: Effect of the carbon source. Appl. Microbiol. 15:1523-1524.

Vidaver, A. K., and Mandel, M. 1974. Corynebacterium nebraskense, a new orange pigmented phytopathogenic species. Int. J. Syst. Bacteriol. 24:482-485.

Willems, A., Goor, M., Thielemans, S., Gillis, M., Kersters, K., and De Ley, J. 1992. Transfer of several phytopathogenic Pseudomonas species to Acidovorax as Acidovorax avenae subsp. avenae subsp. nov., comb. nov., Acidovorax avenae subsp. citrulli, Acidovorax avenae subsp. cattleyae, and Acidovorax konjaci. Int. J. Syst. Bacteriol. 42:107-119

Zheng, Y., Xu, M., Hou, R., Shen, R., Qiu, S., and Ouyang, Z. 2013. Effects of experimental warming on stomatal traits in leaves of maize (Zea may L.) Ecol. Evol. 3:3095-3111. 